\title{
Article \\ Effect of Current Density on the Wear Resistance of Ni-P Alloy Coating Prepared through Immersion-Assisted Jet-Electrodeposition
}

\author{
Jieyu Xian *(D), Zhenyu Shen, Zhengwei Zhang, Hongbin Wu, Meifu Jin and Minjie Jiang \\ College of Engineering, Nanjing Agricultural University, Nanjing 210031, China; 2019812052@njau.edu.cn (Z.S.); \\ weizhzh@njau.edu.cn (Z.Z.); wuhongbin@njau.edu.cn (H.W.); jinmeifu@njau.edu.cn (M.J.); \\ 9173010911@njau.edu.cn (M.J.) \\ * Correspondence: xianjy@njau.edu.cn
}

check for updates

Citation: Xian, J.; Shen, Z.; Zhang, Z.; Wu, H.; Jin, M.; Jiang, M. Effect of Current Density on the Wear Resistance of Ni-P Alloy Coating Prepared through Immersion-Assisted Jet-Electrodeposition. Coatings 2021, 11, 527. https://doi.org/10.3390/ coatings11050527

Academic Editor: Cecilia Bartuli

Received: 14 April 2021

Accepted: 27 April 2021

Published: 29 April 2021

Publisher's Note: MDPI stays neutral with regard to jurisdictional claims in published maps and institutional affiliations.

Copyright: (c) 2021 by the authors. Licensee MDPI, Basel, Switzerland. This article is an open access article distributed under the terms and conditions of the Creative Commons Attribution (CC BY) license (https:// creativecommons.org/licenses/by/ $4.0 /)$.
Abstract: To improve the wear resistance of 45 steel surfaces, a Ni-P alloy coating was prepared on the surface of 45 steel with an immersion-assisted jet-electrodeposition technology. Scanning electron microscopy, energy dispersive spectrometry, X-ray diffraction and confocal microscopy were used in testing the surface morphology, composition, structure, grain size, and wear scar parameters of the coating. The effect of immersion-assisted jet-electrodeposition on the wear resistance of $\mathrm{Ni}-\mathrm{P}$ alloy coating at current densities of $20-60 \mathrm{~A} \cdot \mathrm{cm}^{-2}$ were explored and analyzed. Results showed that the surface quality, microhardness, and wear resistance of $\mathrm{Ni}-\mathrm{P}$ alloy coatings prepared through immersion-assisted jet-electrodeposition were improved compared with those of the coatings prepared through traditional jet-electrodeposition. With the increase in the current density, the surface cell structure of the alloy coating was refined, the flatness was improved, the surface Ni content was increased, the grain size was refined, and the coating thickness, the microhardness, and wear resistance showed a trend of first increasing and then decreasing. The best surface quality of the coating was observed at a current density of $50 \mathrm{~A} \cdot \mathrm{cm}^{-2}$. Moreover, the unit cell structure was obvious, the surface was flat and dense, the coating thickness was the largest, reaching $21.42 \mu \mathrm{m}$, the highest Ni content was obtained $(98.25 \mathrm{wt} . \%)$, the smallest grain size $(6.6 \mathrm{~nm})$ was obtained, the microhardness of the coating reached a maximum value $\left(725.58 \mathrm{HV}_{0.1}\right)$, and the best wear resistance was observed.

Keywords: immersion-assisted jet-electrodeposition; current density; $\mathrm{Ni}-\mathrm{P}$ alloy coating; microhardness; wear resistance

\section{Introduction}

Owing to the rapid development of modern industry, various industries have proposed high requirements for the performance and service lives of mechanical parts. Preparing a coating on the surface of a metal workpiece is one of the important methods used to improve the physical and chemical performance of a substrate and extend its service life. Electrodeposited coatings are currently used in preparing coatings and improving substrate performance, having the advantages of high limiting current density and fast deposition rates. The conditions for electrochemical deposition are the main factors that determine the performance of coatings, such as the current density and electrodeposition methods [1-4]. Jiang et al. [5] found that the surface defects of $\mathrm{Ni}-\mathrm{SiC}$ coatings prepared through magnetic field-assisted jet-electrodeposition were reduced relative to those in $\mathrm{Ni}-\mathrm{SiC}$ coatings prepared through ordinary jet-electrodeposition, and flatness was improved. Xue et al. [6] studied the effect of different electrodeposition methods on the tribological properties of $\mathrm{Ni}-\mathrm{CeO}_{2}$ nanocomposite coatings. Hessam et al. [7] found that thin hematite films with good morphology, small grain size, and high bandgaps could be deposited by increasing the current density during electrodeposition. Shourije et al. [8] observed the excellent 
surface properties of a co-deposited nano-Ni-MoS 2 composite coating at a current density of $5 \mathrm{~A} \cdot \mathrm{dm}^{-2}$.

Jet-electrodeposition is a local high-speed electrodeposition technique. It creates voltage between the anode and cathode by connecting to a power source. A plating solution is sprayed onto the surface of the cathode workpiece at a high flow rate through the anode nozzle to form a closed loop. The ion deposition process is realized under the action of a strong electric field. Compared with traditional electrodeposition, jet-electrodeposition accelerates the transport of electrodeposition materials and increases the limit current density, thereby accelerating the speed of ion deposition. Under the impact of the plating solution, the thickness of the surface diffusion layer is effectively reduced, and the excessive growth of the crystal grains in the vertical direction is suppressed; thus, a dense plating layer structure and refined crystal grains are obtained [9-14]. Compared with a pure $\mathrm{Ni}$ coating, a Ni-P alloy coating has excellent physical, chemical, and mechanical properties, and is an alternative to pure Ni coating as an ideal metal substrate protection layer. The wear resistance, corrosion resistance, superhydrophobicity, oxidation resistance, and heat resistance of coatings are often explored by characterization of the surface morphology, cross-section morphology, phase structure, and element distribution of the coatings. In our previous research, we prepared a $\mathrm{Ni}-\mathrm{P}-\mathrm{SiC}$ coating through scanning jet-electrodeposition after sandblasting pretreatment on the 45 steel substrate. The results showed that the sandblasting pretreatment of the substrate and the addition of SiC nanoparticles can improve adhesion property and corrosion resistance [15]. To improve the surface hardness and wear resistance of 45 steel, Song [10] prepared a $\mathrm{Ni}-\mathrm{P}-\mathrm{ZrO}_{2}-\mathrm{CeO}_{2}$ composite coating on the surface of 45 steel with jet-electrodeposition technology. The results showed the best wear and corrosion resistance at a current density of $40 \mathrm{~A} \cdot \mathrm{dm} \mathrm{m}^{-2}$. These studies laid a theoretical foundation for the surface protection of 45 steel substrates and improvements in jet-electrodeposition technology.

In the jet-electrodeposition process, the surface of a workpiece is exposed to the air above a plating solution, which is in an unstable environment. When the current density is extremely large, concentration polarization is caused by increases in the deposition speed of ions and subsequent decreases in coating performance [10]. To alleviate the above problems, we proposed an ameliorative direction for the jet-electrodeposition process: a method combining traditional and spray electrodeposition was used in preparing a workpiece and a nozzle that would be submerged in the plating solution for immersionassisted jet-electrodeposition. The influence of jet-electrodeposition on the deposition of the workpiece immersed in the plating solution has not been explored. Immersion-assisted jet-electrodeposition is a new coating surface modification deposition process based on jetelectrodeposition. Using the current electrodeposition $\mathrm{Ni}-\mathrm{P}$ alloy process, we compared the immersion-assisted jet-electrodeposition with traditional jet-electrodeposition to explore the effects of different current densities on the wear resistance of $\mathrm{Ni}-\mathrm{P}$ coatings prepared by immersion-assisted jet-electrodeposition, thus promoting the development of the jetelectrodeposition process.

\section{Experimental Materials and Method}

\subsection{Equipment and Principle of Immersion-Assisted Jet-Electrodeposition}

The electrodeposition process is shown in Figure 1. Figure 1a shows the experimental device. A nozzle with a nickel rod connected to the positive pole of a direct current (DC) power supply was installed on the spindle of the machine tool, and the machine tool was controlled by a computer, which ensured the reciprocating movement of the nozzle above the surface of the workpiece. The workpiece was fixed on a special fixture and connected to the negative pole of the DC power supply. During the electrospray plating process, the workpiece was immersed in a plating solution. The water pump drew the plating solution from the constant temperature storage tank into the anode nozzle and sprayed it onto the surface of the workpiece. Then, the plating solution returned to the constant temperature storage tank through the return pipe for the circulation of the plating solution. After 
the power was turned on, the anode nickel rod, plating solution, and cathode workpiece formed a closed loop. Under the action of a strong electric field, metal ions were deposited.
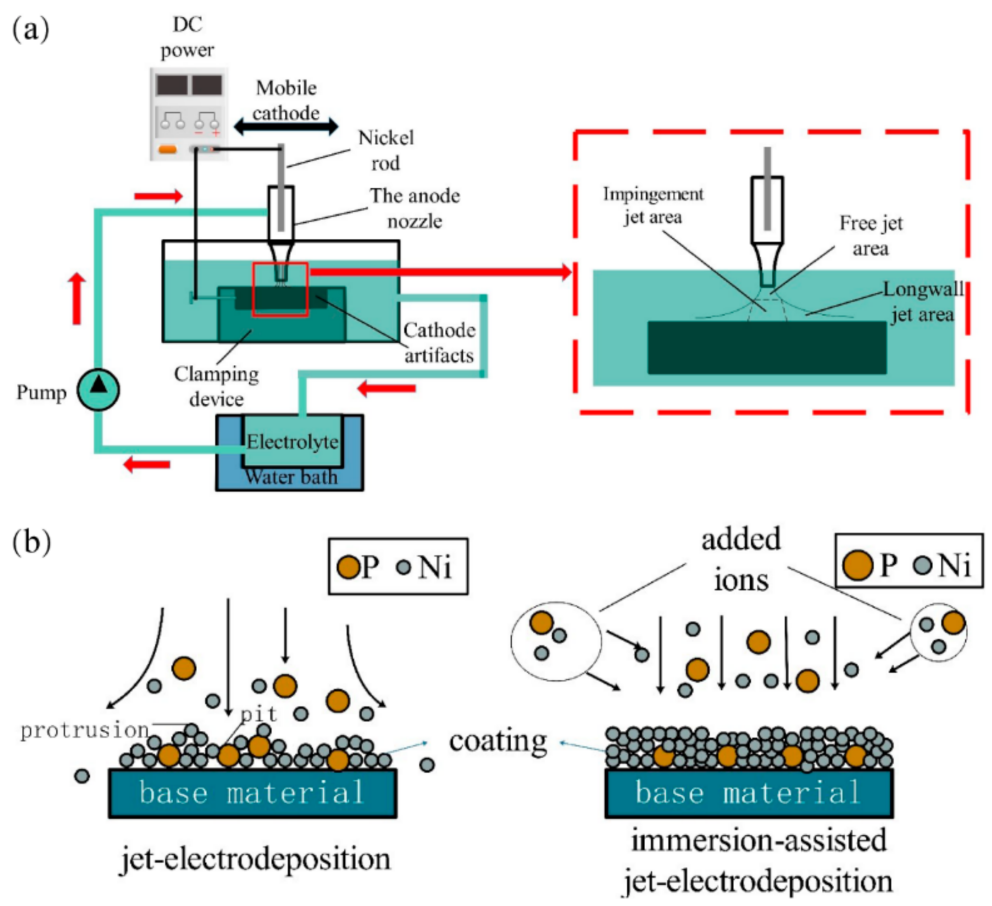

Figure 1. Schematic diagram of electrodeposition process. (a) Experimental device; (b) electrodeposition principle.

The principle of immersion-assisted jet-electrodeposition is shown in Figure $1 \mathrm{~b}$. The workpieces in immersion-assisted jet-electrodeposition are immersed in the plating solution. This procedure provides the workpiece with a stable environment during processing. When the workpiece is immersed in the plating solution, the gap between the anode nozzle and cathode workpiece and other surrounding areas are filled with the plating solution; thus, the medium between the cathode and anode becomes uniform, and the electric field between the anode and cathode becomes stable. In addition, the temperature of the plating solution around the workpiece is uniform and high, which accelerates the diffusion of ions [16]. Therefore, when the limiting current density of the deposition continues to increase, $\mathrm{Ni}^{2+}$ in the reaction zone can be replenished quickly by the surrounding plating solution, which alleviates the concentration polarization phenomenon caused by excessively rapid deposition during traditional jet-electrodeposition.

\subsection{Preparation of the Workpiece and Coatings}

The composition of the plating solution is provided in Table 1. A $\mathrm{NiSO}_{4}$ solution served as the main source of $\mathrm{Ni}^{2+}$ in the solution; a $\mathrm{NiCl}_{2}$ solution was used as an anodic activator to prevent anodic passivation; $\mathrm{a}_{3} \mathrm{PO}_{3}$ solution provided $\mathrm{P}$ atoms for the coating; a $\mathrm{H}_{3} \mathrm{BO}_{3}$ solution was used as the buffer reagent to adjust the $\mathrm{pH}$ value in the bath; $\mathrm{C}_{6} \mathrm{H}_{8} \mathrm{O}_{7}$ (citric acid) was used as a complexing agent to prevent precipitation in the electrochemical reaction, increase the deposition rate and stability, and improve the coating quality; and $\mathrm{CH}_{4} \mathrm{~N}_{2} \mathrm{~S}$ (thiocarbamide) was used as a whitener to refine the grain size. $\mathrm{C}_{12} \mathrm{H}_{25} \mathrm{SO}_{4} \mathrm{Na}$ (sodium dodecyl sulfonate) was used as a surfactant. A 45 steel workpiece $(25 \mathrm{~mm} \times 10 \mathrm{~mm} \times 8 \mathrm{~mm})$ was used as the base material. The main component of 45 steel is Fe, and the compositions of the remaining elements are shown in Table 2. It was polished with sandpaper with 320, 800 and 1500 grits. The 3D morphology of the 45 steel after polishing pretreatment is shown in Figure 2. The surface morphology of the 45 steel surface is shown in Figure 3. The surface square root roughness of 45 steel substrate with polishing 
pretreatment was 0.006 , and the root mean square roughness was 0.008 . The activation steps are as follows: oil removal $\rightarrow$ ultrasonic cleaning $\rightarrow$ weak activation $\rightarrow$ ultrasonic cleaning $\rightarrow$ strong activation $\rightarrow$ ultrasonic cleaning $\rightarrow$ blow dry $\rightarrow$ seal. The function of drying and sealing the workpiece is to prevent oxidation.

Table 1. Composition of the plating solution.

\begin{tabular}{cc}
\hline Composition & Content/(g. $\left.\mathbf{L}^{-\mathbf{1}}\right)$ \\
\hline $\mathrm{NiSO}_{4} \cdot 6 \mathrm{H}_{2} \mathrm{O}$ & 200 \\
$\mathrm{NiCl}_{2} \cdot 6 \mathrm{H}_{2} \mathrm{O}$ & 30 \\
$\mathrm{H}_{3} \mathrm{PO}_{3}$ & 20 \\
$\mathrm{H}_{3} \mathrm{BO}_{3}$ & 30 \\
$\mathrm{C}_{6} \mathrm{H}_{8} \mathrm{O}_{7}$ & 60 \\
$\mathrm{CH}_{4} \mathrm{~N}_{2} \mathrm{~S}$ & 0.01 \\
$\mathrm{C}_{12} \mathrm{H}_{25} \mathrm{SO}_{4} \mathrm{Na}$ & 0.08 \\
\hline
\end{tabular}

Table 2. Chemical element composition of 45 steel (wt.\%).

\begin{tabular}{ccccccc}
\hline Element & $\mathbf{C}$ & $\mathbf{S i}$ & $\mathbf{M n}$ & $\mathbf{C r}$ & $\mathbf{N i}$ & $\mathbf{C u}$ \\
\hline Content & $0.42-0.50$ & $0.17-0.37$ & $0.50-0.80$ & $\leq 0.25$ & $\leq 0.30$ & $\leq 0.25$ \\
\hline
\end{tabular}

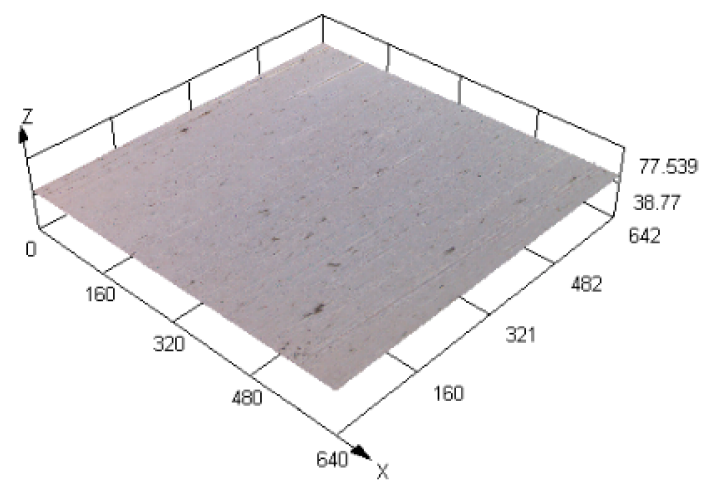

Figure 2. Three-dimensional morphology of the 45 steel.

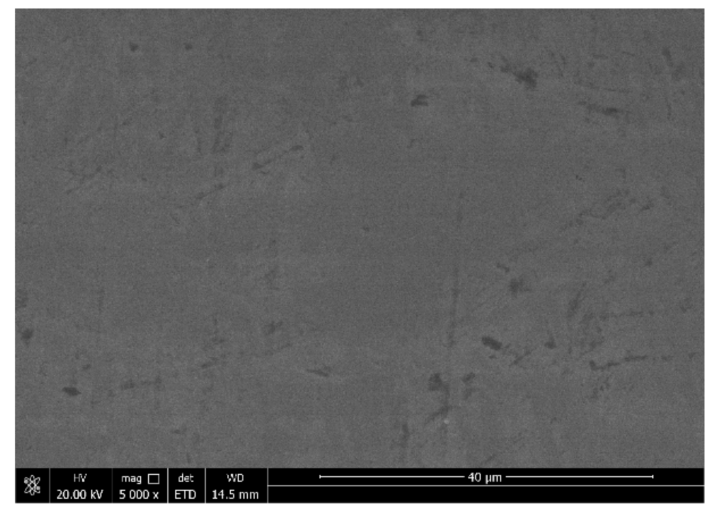

Figure 3. Surface morphology of the 45 steel.

The depth of the workpiece immersed in the plating solution was $20 \mathrm{~mm}$. The current densities during deposition were $20,30,40,50$ and $60 \mathrm{~A} \cdot \mathrm{cm}^{-2}$. According to the preliminary tests, the flow velocity was $4.5 \mathrm{~m} \cdot \mathrm{s}^{-1}$, and a temperature of $65^{\circ} \mathrm{C}$ had the better effect on the processing area and had good surface quality and wear resistance. According to the previous test, the flow rate was set at $4.5 \mathrm{~m} \cdot \mathrm{s}^{-1}$, and the bath temperature was set at $65^{\circ} \mathrm{C}$. 


\subsection{Testing Equipment}

A scanning electron microscope (FEI-SEM, Quanta FEG250; FEI Instruments, Hillsboro, OR, USA) was used in observing and analysing the surface morphology of the coating and the surface morphology of the coating wear scar. The image type of the secondary electron image was selected for observation. The acceleration voltage was set at $3-15 \mathrm{kV}$, the scanning speed was $20 \mu$ s and 100-30,000 $\times$ magnification was used.

An energy dispersive spectrometer (EDS; XFlash 5030 BrukerAXS, Inc., Berlin, Germany) was used in determining the chemical composition of the coating. The energy spectrometer is often used in conjunction with scanning electron microscopy, which is used in quantitatively and qualitatively analysing related elements in the related regions of a microscopic surface topography in a short time. It is an important supporting instrument.

Microstructure, grain size and phase composition were analyzed with an X-ray diffraction system (XRD; PANalytical X'pert; PANalytical Inc., Malvern, UK). The equipment parameters were as follows: working voltage, $40 \mathrm{kV}$, the scanning range $(2 \theta), 20^{\circ}-90^{\circ}$ and scanning rate, $5^{\circ} \cdot \mathrm{min}^{-1}$.

A micro-hardness tester (Duramin-40; Strous, Ballerup, Denmark) was used to measure the micro-hardness of the coating. The measurement method of microhardness was held for $15 \mathrm{~s}$ under a load of $100 \mathrm{~g}$, and the average of five measurements was obtained.

A CFT-I type material surface performance comprehensive tester was used in the friction and wear test. A grinding ball with a diameter of $5 \mathrm{~mm}$ was used for reciprocating grinding on the surface of the coating for $20 \mathrm{~min}$. The reciprocating speed was set at $500 \mathrm{~T} \cdot \mathrm{min}^{-1}$, the wear scar length was $4 \mathrm{~mm}$ and the load was $320 \mathrm{~g}$. The selected parameters used in characterising the wear marks on the coating surface were width, depth and cross-sectional area.

We measured wear morphology with an OLYMPUS LEXT OLS4100 laser confocal microscope. Images were collected through laser scanning in a non-contact way and used in observing the three-dimensional morphology and measuring the roughness of the sample surface. The maximum magnification was $17 \mathrm{~m} 280 \times$, and the maximum resolution was $10 \mathrm{~nm}$.

\section{Result and Discussion}

\subsection{Analysis of the Surface Morphology of the Coating}

The surface micro-morphology of the Ni-P alloy coatings prepared through immersionassisted jet-electrodeposition and jet- electrodeposition at different current densities is shown in Figure 4 . Here, $30 \mathrm{~A} \cdot \mathrm{dm}^{-2}(\mathrm{~J})$ represents traditional jet-electrodeposition at a current density of $30 \mathrm{~A} \cdot \mathrm{dm}^{-2} ; 30 \mathrm{~A} \cdot \mathrm{dm}^{-2}$ represents immersion-assisted jet-electrodeposition at a current density of $30 \mathrm{~A} \cdot \mathrm{dm}^{-2}$. The surface of the coatings had a typical cell structure, and the flatness and density of the coatings changed to a certain extent after the process and current density were changed. The Ni-P alloy coating prepared by jet-electrodeposition is shown in Figure 4a. The surface had a clear cell structure with clear boundaries, and agglomeration between the cells led to the formation of nodules (region A), but many pits and protrusions appeared on the surface, and the surface density was low. Figure $4 b-f$ show Ni-P alloy coatings prepared through immersion-assisted jet-electrodeposition. The surface morphology of the coatings improved to a certain extent (regions B, C, D, E and F). With increasing current density, the surface quality of the coating surface tended to increase first and then decrease. Figure $4 \mathrm{~d}$ shows that the cell structures on the surface of the coating electrodeposited at $40 \mathrm{~A} \cdot \mathrm{dm}^{-2}$ were refined, the boundaries became blurred, and the number of pits and protrusions decreased (region D). The main reason was that immersion-assisted jet-electrodeposition improves the limiting current density, greatly accelerating the deposition rate of $\mathrm{Ni}^{2+}$ [17]. In addition, the workpiece area immersed in the plating solution increased the deposition area per unit time, which provided additional cellular structures nucleation attachment points. It alleviated the unstable state of the deposition process of $\mathrm{Ni}^{2+}$ on the cathode surface as the nozzle reciprocated. When the current density increased from 40 to $50 \mathrm{~A} \cdot \mathrm{dm}^{-2}$ (Figure $4 \mathrm{e}$ ), no obvious cell structure 
appeared on the surface of the coating. When the current density was $50 \mathrm{~A} \cdot \mathrm{dm}^{-2}$, the coating surface was very flat, and the density increased (region E). Cathode overpotential increased with current density. Although such increase is known to promote the nucleation of a cathode workpiece surface $[17,18]$, when the current density continued to increase to $60 \mathrm{~A} \cdot \mathrm{dm}^{-2}$, the surface quality of the coating deteriorated (Figure $4 \mathrm{f}$; region F). When the current density continued to increase, it caused concentration polarization near the cathode workpiece [17-19]. The rapid deposition of $\mathrm{Ni}^{2+}$ ions reduced the ion concentration around the cathode and coarsened the grains.

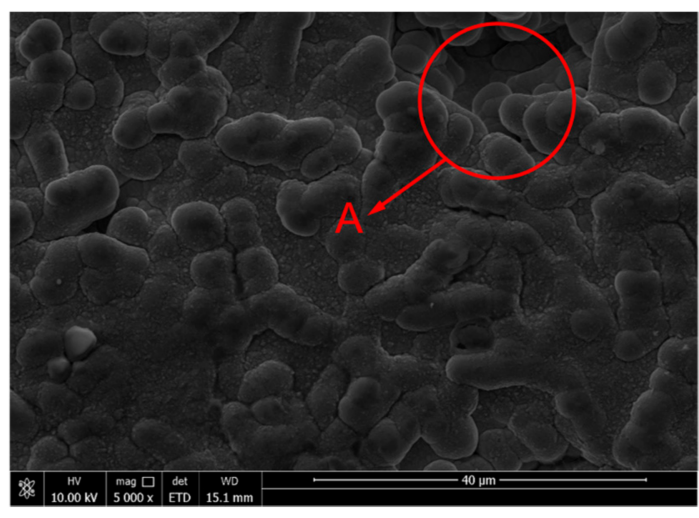

(a)

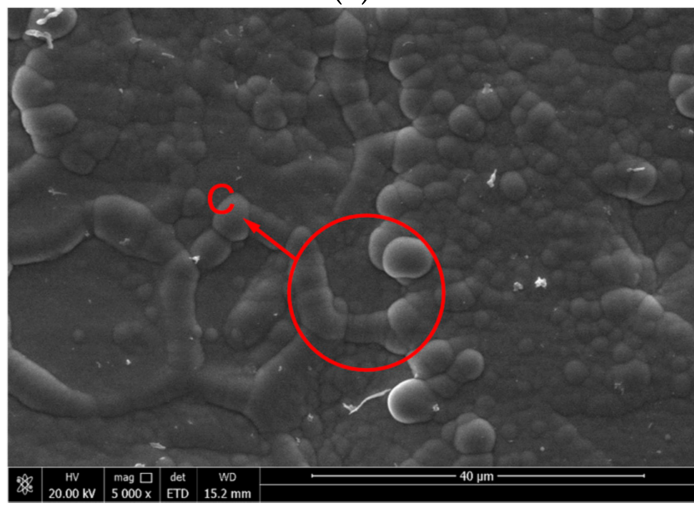

(c)

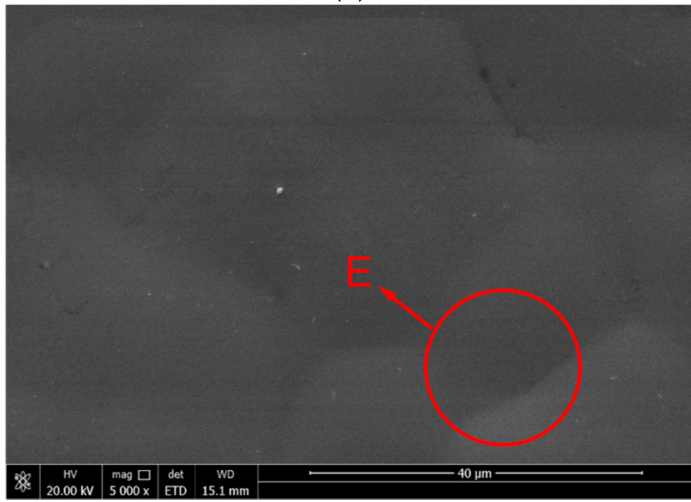

(e)

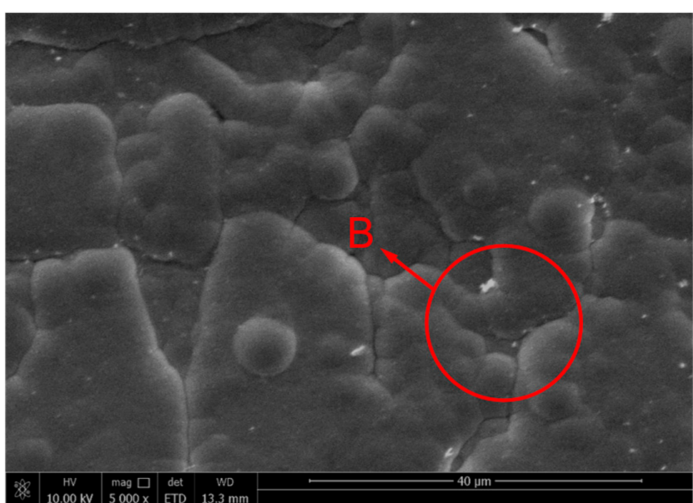

(b)

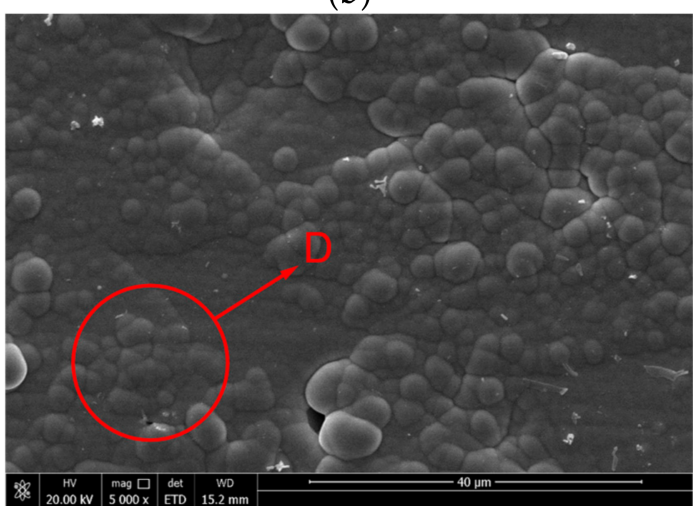

(d)

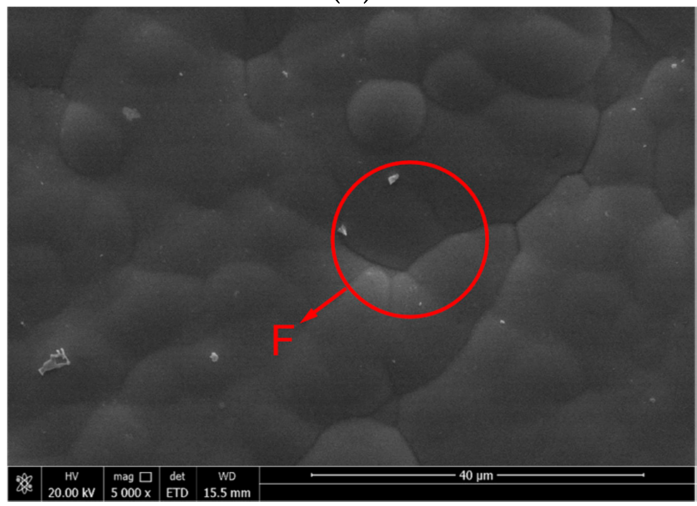

(f)

Figure 4. Surface micro-morphology of the coating. (a) $30 \mathrm{~A} \cdot \mathrm{dm}^{-2}(\mathrm{~J})$ (b) $20 \mathrm{~A} \cdot \mathrm{dm}^{-2}$ (c) $30 \mathrm{~A} \cdot \mathrm{dm}^{-2}$ (d) $40 \mathrm{~A} \cdot \mathrm{dm} \mathbf{m}^{-2}$ (e) $50 \mathrm{~A} \cdot \mathrm{dm}^{-2}$ (f) $60 \mathrm{~A} \cdot \mathrm{dm} \mathrm{m}^{-2}$.

The section micro-morphology of Ni-P alloy coatings prepared by immersion-assisted jet-electrodeposition and jet-electrodeposition at different current densities are shown in Figure 5. Figure 5a shows the section micro-morphology of a Ni-P alloy coating prepared by traditional jet-electrodeposition with a thickness of $18.78 \mu \mathrm{m}$. The section micro- 
morphology of the Ni-P alloy coating prepared by immersion-assisted jet-electrodeposition is shown in Figure $5 \mathrm{~b}-\mathrm{f}$. It could be seen that with increasing current density, the thickness of the coating tended to increase first and then decrease. When the current density was $30 \mathrm{~A} \cdot \mathrm{dm}^{-2}$, the thickness of the Ni-P coating was $19.05 \mu \mathrm{m}$, which indicates that, compared with traditional jet-electrodeposition, immersion jet-electrodeposition increased the surface growth area of the coating, increased the nucleation point of the cell, and accelerated the deposition rate. When the current density was $50 \mathrm{~A} \cdot \mathrm{dm}^{-2}$, the thickness of the Ni-P coating reached the maximum, which was $21.42 \mu \mathrm{m}$, indicating that the immersion jetelectrodeposition increased the limiting current density of the coating. At this time, the current density of the deposited coating was the best and the deposition growth rate was the fastest.

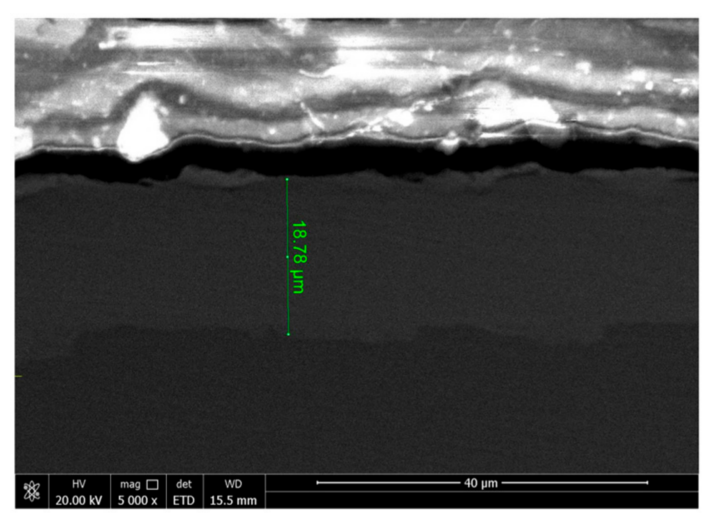

(a)

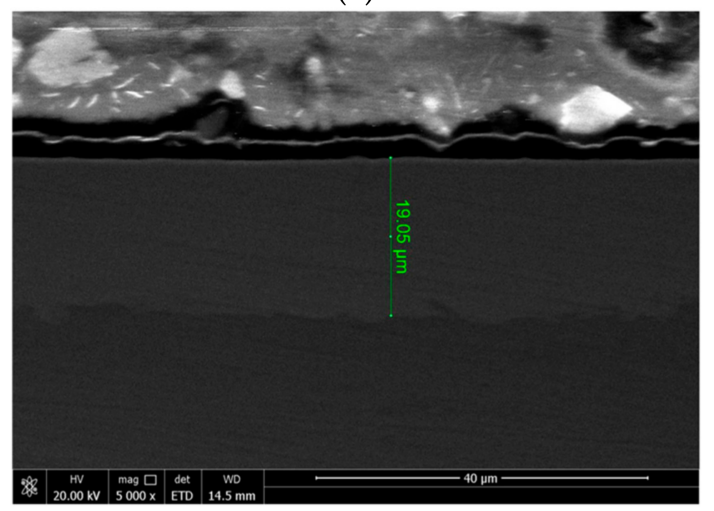

(c)

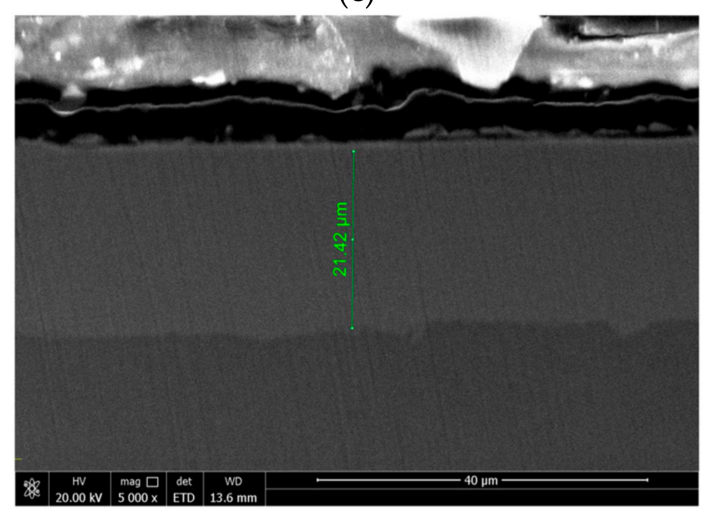

(e)

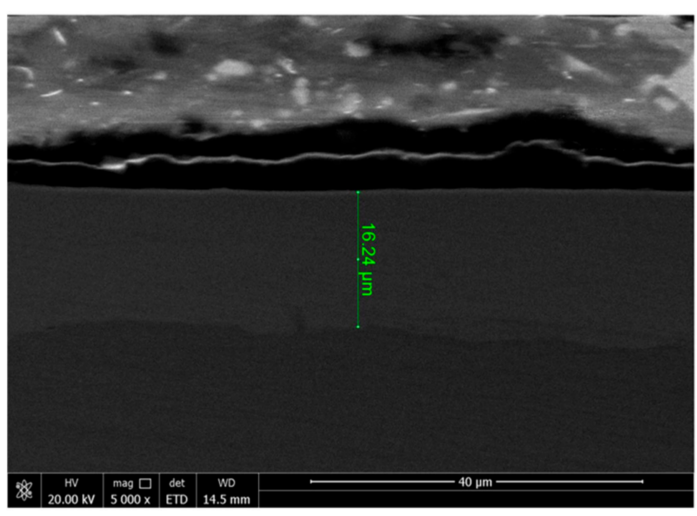

(b)

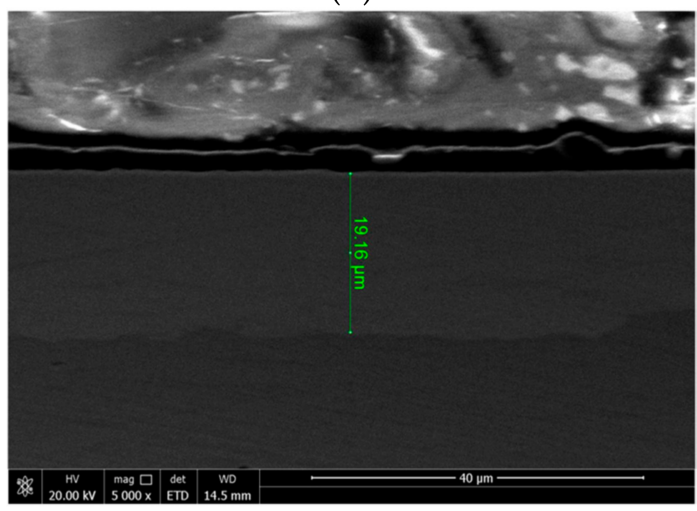

(d)

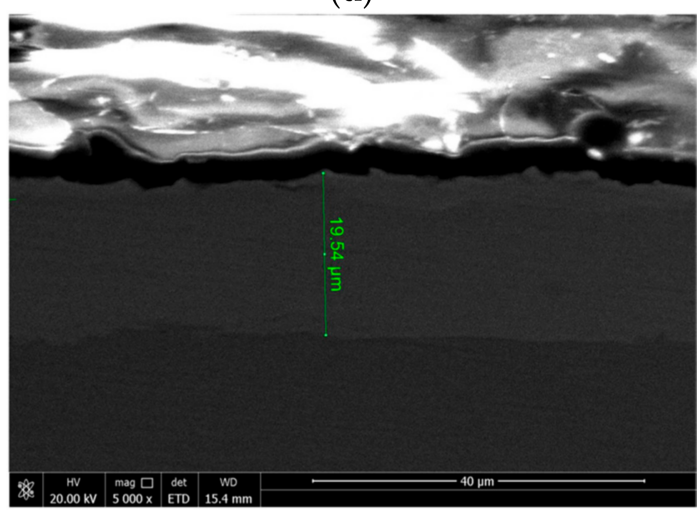

(f)

Figure 5. Section micro-morphology of the coating. (a) $30 \mathrm{~A} \cdot \mathrm{dm}^{-2}$ (b) $20 \mathrm{~A} \cdot \mathrm{dm}^{-2}$ (c) $30 \mathrm{~A} \cdot \mathrm{dm} \mathrm{m}^{-2}$ (d) $40 \mathrm{~A} \cdot \mathrm{dm}{ }^{-2}$ (e) $50 \mathrm{~A} \cdot \mathrm{dm}^{-2}$ (f) $60 \mathrm{~A} \cdot \mathrm{dm} \mathrm{m}^{-2}$. 


\subsection{Analysis of Elemental Composition and Microstructure of the Coating}

The Ni-P alloy coatings prepared through immersion-assisted jet-electrodeposition and spray electrodeposition were tested by EDS. The analysis results of the element content are shown in Table 3, where $30(\mathrm{~J})$ represents the $\mathrm{Ni}-\mathrm{P}$ alloy coating prepared through traditional jet-electrodeposition at a current density of $30 \mathrm{~A} \cdot \mathrm{dm}^{-2}$. The Ni content in the $\mathrm{Ni}-\mathrm{P}$ coating prepared through immersion-assisted jet-electrodeposition was higher than that of the $\mathrm{Ni}-\mathrm{P}$ coating prepared through jet-electrodeposition. At the same or lower current density, the immersion-assisted jet-electrodeposition of the workpiece immersed in the plating solution reduced the unevenness of the plating layer because of the uneven jet of the plating solution, and thus $\mathrm{Ni}^{2+}$ deposition was more stable. The workpiece immersed in the plating solution absorbed the temperature of the plating solution, and the process eliminated the influence of the temperature gradient generated in the impingement jet and free jet areas because of the difference between the temperatures of the workpiece surface and plating solution during jet-electrodeposition. It accelerated the free movement and deposition rate of $\mathrm{Ni}^{2+}$ [16]. Moreover, when the current density was increased from 20 to $50 \mathrm{~A} \cdot \mathrm{dm}^{-2}$, the Ni content increased with current density. The increase in current density accelerated the $\mathrm{Ni}^{2+}$ deposition rate, resulting in an increase in the Ni content in the coating. When the current density was $60 \mathrm{~A} \cdot \mathrm{dm}^{-2}$, the Ni content in the coating decreased. As the current density increased, the increase in cathode polarization accelerated the depletion of $\mathrm{Ni}^{2+}$ in the diffusion layer near the cathode, resulting in a decrease in the concentration of $\mathrm{Ni}^{2+}$ in the plating solution near the cathode. This decrease is a characteristic of the concentration polarization phenomenon, which reduced the $\mathrm{Ni}$ content in the coating. However, under different current densities, the $\mathrm{P}$ content in the coating tended to be stable mainly because $\mathrm{Ni}-\mathrm{P}$ deposition is an indirect induced co-deposition [20].

Table 3. The quality fraction of the surface elements of the coating.

\begin{tabular}{|c|c|c|}
\hline Current Density/(A.dm $\left.{ }^{-2}\right)$ & $\mathrm{Ni} /(w t . \%)$ & $\mathrm{P} /($ wt. $\%)$ \\
\hline $30(\mathrm{~J})$ & 70.78 & 1.94 \\
\hline 20 & 79.26 & 0.77 \\
\hline 30 & 84.32 & 1.98 \\
\hline 40 & 89.84 & 1.38 \\
\hline 50 & 98.25 & 1.73 \\
\hline 60 & 82.28 & 3.45 \\
\hline
\end{tabular}

Figure 6 is the XRD diffraction pattern of the $\mathrm{Ni}-\mathrm{P}$ alloy coating under different parameters and different manufacturing processes. A high-intensity diffraction peak appeared in the patterns of all the coatings near a 2-theta angle of $45^{\circ}$, which represented the (111) plane of a face-centered cubic Ni. The (111) plane was the dominant plane, which may be related to the lower surface energy of this plane during deposition [21]. The XRD diffraction peak of $P$ in the line graph is not obvious. The EDS analysis results showed that the content of $\mathrm{P}$ in the coating was much lower than that of $\mathrm{Ni}$, and thus the diffraction peak of $\mathrm{P}$ was extremely weak. Moreover, $\mathrm{Ni}$ and $\mathrm{P}$ ions formed a supersaturated solid solution of Ni during deposition [22], and finally caused the diffraction peaks of $\mathrm{Ni}$ and $\mathrm{P}$ to coincide. Table 4 shows the grain sizes of $\mathrm{Ni}$ (111) in the $\mathrm{Ni}-\mathrm{P}$ coatings prepared at different current densities, where $30(\mathrm{~J})$ represents $\mathrm{Ni}-\mathrm{P}$ coatings prepared by jet-electrodeposition. When the current density was $50 \mathrm{~A} \cdot \mathrm{dm}^{-2}$, the grain size of $\mathrm{Ni}$ (111) element in the $\mathrm{Ni}-\mathrm{P}$ coating prepared through immersion-assisted jet-electrodeposition was the smallest $(6.6 \mathrm{~nm})$. When the current density was 20 or $60 \mathrm{~A} \cdot \mathrm{dm}^{-2}$, the grain size increased to 8.8 or $7.2 \mathrm{~nm}$, respectively. Owing to an increase in current density, the deposition rate of the ions and the nucleation rate increased, and thus the grains were refined. However, when the current density continued to increase, the grains became coarse with the occurrence of concentration polarization. As shown in Table 4, the grain size of $\mathrm{Ni}$ (111) element in the $\mathrm{Ni}-\mathrm{P}$ coating prepared through traditional jet-electrodeposition was smaller than that of the coating prepared through immersion-assisted jet-electrodeposition. 
The reasons may be that the impact energy of the plating solution on the coating was strong and the coating was mechanically activated during tradition jet-electrodeposition; these effects may have resulted in fine plating particles [13].

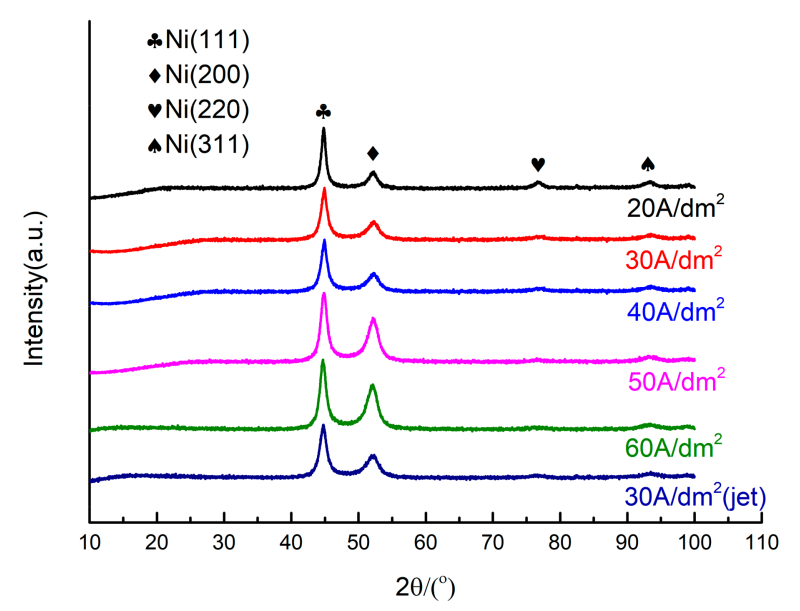

Figure 6. XRD pattern of Ni-P alloy coatings.

Table 4. Grain size of $\mathrm{Ni}(111)$ element in Ni-P coatings.

\begin{tabular}{ccc}
\hline Current Density/(A·dm & $\mathbf{- 2})$ & $\mathbf{D} /(\mathbf{n m})$ \\
\hline $30(\mathrm{~J})$ & $\left.44 / \mathbf{(}^{\mathbf{0}}\right)$ & 6.6 \\
20 & 4459 & 8.8 \\
30 & 4.836 & 7.0 \\
40 & 44.973 & 6.7 \\
50 & 44.807 & 6.6 \\
60 & 44.900 & 7.2 \\
\hline
\end{tabular}

\subsection{Analysis of Microhardness of Coating}

The microhardness of the coating prepared through jet-electrodeposition was $612.31 \pm 15.71$ $\mathrm{HV}_{0.1}$. Figure 7 reflects the microhardness of the coatings prepared through immersionassisted jet-electrodeposition at different current densities. To test the microhardness, we measured five values on the surface of the coating, obtained the average value as the measurement result, and calculated the error range as the uncertainty. The microhardness of the coatings prepared through immersion-assisted jet-electrodeposition improved compared with that of the coatings prepared through jet-electrodeposition. The average microhardness of the $\mathrm{Ni}-\mathrm{P}$ alloy coating prepared through immersion-assisted jet-electrodeposition reached a maximum value of $725.58 \pm 21.56 \mathrm{HV}_{0.1}$ at a current density of $50 \mathrm{~A} \cdot \mathrm{dm}^{-2}$. Microhardness increased by $18.50 \%$ compared with that of the coating prepared through jet-electrodeposition. The reason was that the immersion of the workpiece in the plating solution greatly accelerated the deposition rate, resulting in the higher density of the coating. However, when the current density increased to $60 \mathrm{~A} \cdot \mathrm{dm}^{-2}$, the microhardness of the coating decreased, and surface quality deteriorated. The reason was that when the current density continued to increase, the cathodic hydrogen evolution reaction intensified, increasing the concentration difference polarization of the plating solution during deposition, the grain size, and the degree of hydrogen permeation of the coating; these effects led to the appearance of surface defects and reduced the hardness of the coatings [10]. In addition, the edge effect became obvious with increasing current density and reduced the surface quality and the microhardness of the coating. 


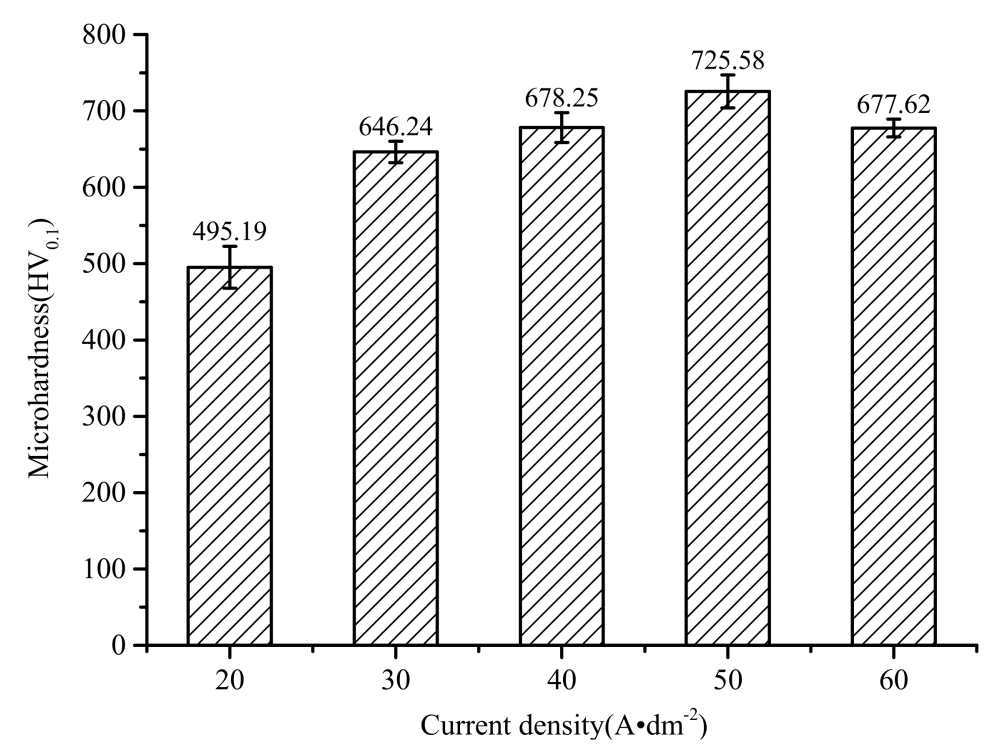

Figure 7. Microhardness of Ni-P alloy coatings prepared by immersion-assisted jet-electrodeposition at different current densities.

\subsection{Analysis of the Wear Resistance of the Coating}

Under the conditions of room temperature $\left(25^{\circ} \mathrm{C}\right)$ and no lubrication, a CFT-I material surface performance comprehensive tester was used in conducting friction and wear tests on the coating. The three-dimensional morphology and parameters of the wear scars of the coatings prepared under different current densities detected by the confocal microscope are shown in Figure 8 and Table 5, respectively. In this test, the wear resistance of the coating was determined from the width, depth, cross-sectional area, and friction mechanism of the wear scar. Figure 8 and Table 5 show that the width, depth, and cross-sectional area of the Ni-P coating prepared through immersion-assisted jet-electrodeposition were smaller than those of the coating prepared through jet-electrodeposition. After immersion-assisted jet-electrodeposition, the wear scar parameters of the coating first decreased and then increased with increasing current density. Under the same wear scar length, the amount of wear on the coating decreased with depth, cross-sectional area size, and wear scar width, indicating enhanced wear resistance [23]. The best wear resistance and the smallest width, depth, and cross-sectional area of the wear scar were observed at a current density of $50 \mathrm{~A} \cdot \mathrm{dm}^{-2}$. Under this current density, the coating grains were uniform, the surface was flat, the density was high, and the ability to resist plastic deformation was strong, consistent with the microhardness analysis above. As the current density increased to $60 \mathrm{~A} \cdot \mathrm{dm}^{-2}$, the width, depth, and cross-sectional area of the coating's wear scar increased. The main reason is that when the current density is large, the uneven grain growth of the plating layer causes the density to decrease, and the ability to resist plastic deformation decreases.

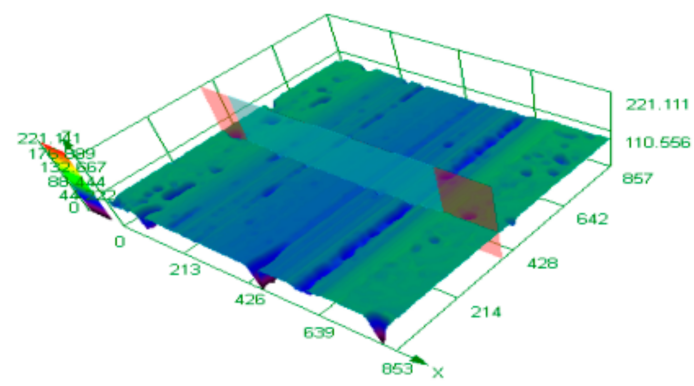

(a)

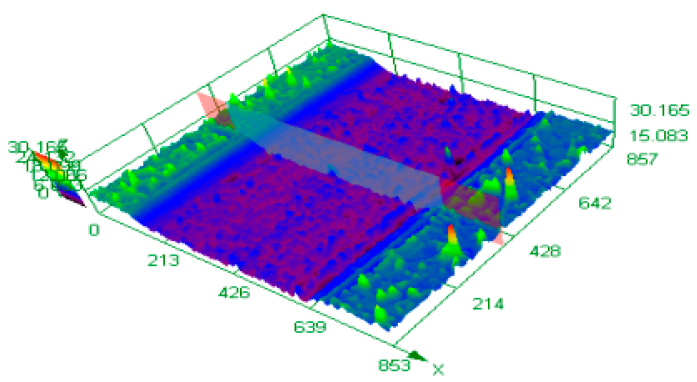

(b)

Figure 8. Cont. 


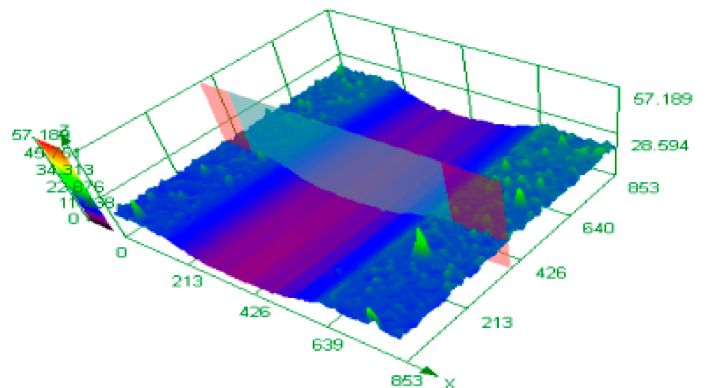

(c)

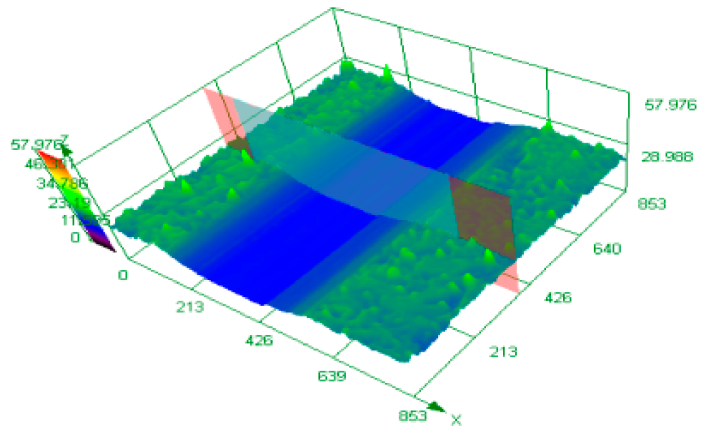

(e)

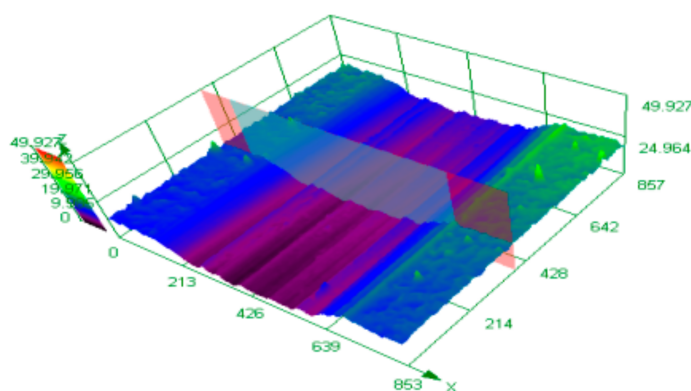

(d)

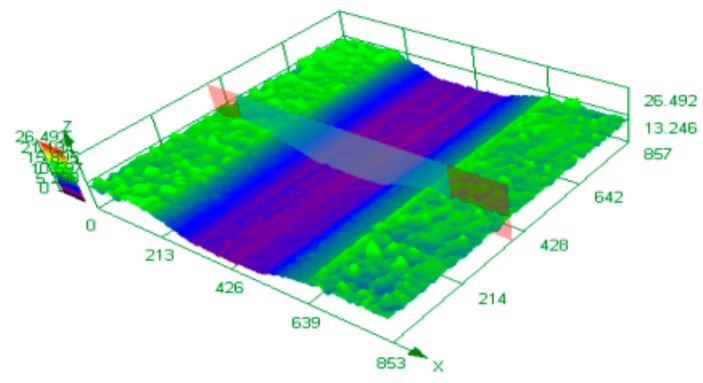

$(\mathbf{f})$

Figure 8. Three-dimensional morphology of wear marks. (a) $30 \mathrm{~A} \cdot \mathrm{dm}^{-2}(\mathrm{~J}),(\mathbf{b}) 20 \mathrm{~A} \cdot \mathrm{dm}^{-2}$ (c) $30 \mathrm{~A} \cdot \mathrm{dm}^{-2}(\mathrm{~d}) 40 \mathrm{~A} \cdot \mathrm{dm}{ }^{-2}$ (e) $50 \mathrm{~A} \cdot d m^{-2}$ (f) $60 \mathrm{~A} \cdot \mathrm{dm}^{-2}$.

Table 5. Coating wear mark parameters.

\begin{tabular}{|c|c|c|c|}
\hline $\begin{array}{c}\text { Current } \\
\left.\text { Density/(A.dm }{ }^{-2}\right)\end{array}$ & $\begin{array}{l}\text { Width/ } \\
(\mu \mathrm{m})\end{array}$ & $\begin{array}{l}\text { Height/ } \\
(\mu \mathrm{m})\end{array}$ & $\begin{array}{c}\text { Scratch/ } \\
\text { Area }\left(\mu \mathrm{m}^{2}\right)\end{array}$ \\
\hline $30(\mathrm{~J})$ & $603.140 \pm 15.372$ & $13.620 \pm 1.232$ & $5039.194 \pm 105.577$ \\
\hline 20 & $592.257 \pm 18.266$ & $11.623 \pm 1.839$ & $3922.100 \pm 152.228$ \\
\hline 30 & $516.905 \pm 18.952$ & $11.191 \pm 1.325$ & $3623.217 \pm 131.174$ \\
\hline 40 & $510.434 \pm 14.275$ & $10.607 \pm 0.923$ & $3204.018 \pm 138.380$ \\
\hline 50 & $425.494 \pm 10.338$ & $7.782 \pm 0.574$ & $2266.533 \pm 101.909$ \\
\hline 60 & $465.117 \pm 16.159$ & $8.441 \pm 1.391$ & $2593.077 \pm 146.263$ \\
\hline
\end{tabular}

After the friction and wear test, the morphology of the coating wear scar was analyzed through SEM. The morphology is shown in Figure 9. As shown in Figure 9a, a large number of furrows appeared on the wear surface of the $\mathrm{Ni}-\mathrm{P}$ coating prepared through spray electrodeposition, and many pits and protrusions appeared because the coating fell off (region A). The friction mechanism was adhesive wear and surface fatigue wear. The main reason was that the heat generated by friction softened the $\mathrm{Ni}-\mathrm{P}$ alloy coating. In addition, plastic deformation occurred at the contact point. As the grinding ball slid back and forth on the coating surface, the adhesion point was cut off under the action of shear stress, which resulted in the migration of materials on the surface to form furrows. After the 'sinusoid-like signal' change of the shear stress on the coating surface had occurred, the coating surface hardened because of fatigue wear and falling off. The furrows, bumps, and pits on the wear scar surface of the $\mathrm{Ni}-\mathrm{P}$ coating prepared through immersion-assisted jet-electrodeposition were significantly reduced, and the friction mechanism was mainly abrasive wear. The main reason was that in immersion-assisted jet-electrodeposition, the ion deposition rate is faster, and the electric field is more stable. Thus, the $\mathrm{Ni}-\mathrm{P}$ coating prepared was denser and had a higher degree of microhardness [10]. According to Archard's law [24], under the same test conditions, the wear resistance of a coating is proportional to its microhardness. In Figure $9 b-d$, slight cracks appeared on the surface of the wear scar, but the surface quality of the wear scar greatly improved (regions B, C and D), 
suggesting that the bonding of the coating to the substrate was not particularly tight and cracks were generated during the wear process because the current density was slightly smaller [7]. When the current density increased to $50 \mathrm{~A} \cdot \mathrm{dm}^{-2}$, as shown in Figure $9 \mathrm{e}$, no obvious furrow or shedding phenomenon occurred on the surface of the coating wear scar, and no cracks appeared (region E). The friction mechanism was mainly based on abrasive wear. However, as the current density continued to increase to $60 \mathrm{~A} \cdot \mathrm{dm}^{-2}$, obvious cracks appeared on the surface of the wear scar of the coating, as shown in Figure $9 \mathrm{f}$ (region F). Current density increased during the deposition process, and thus the P content and the amount of supersaturated solid solution of $\mathrm{Ni}$ in the coating increased [22]. A strong internal stress was generated, and a crack was generated during the wear process.

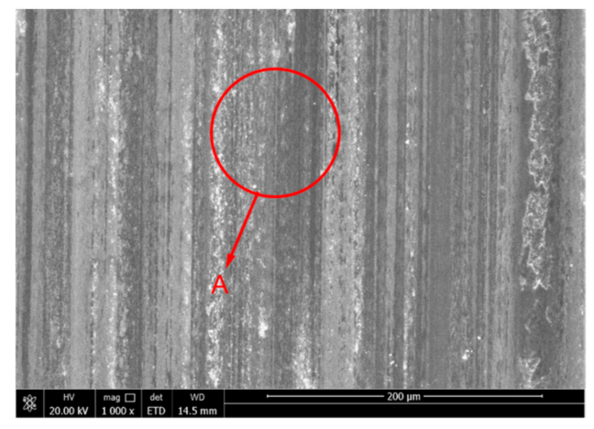

(a)

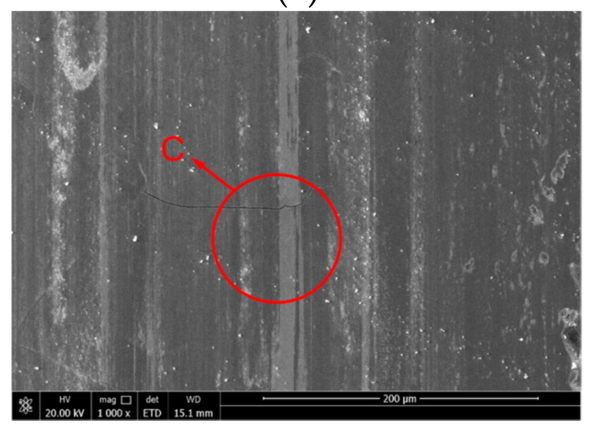

(c)

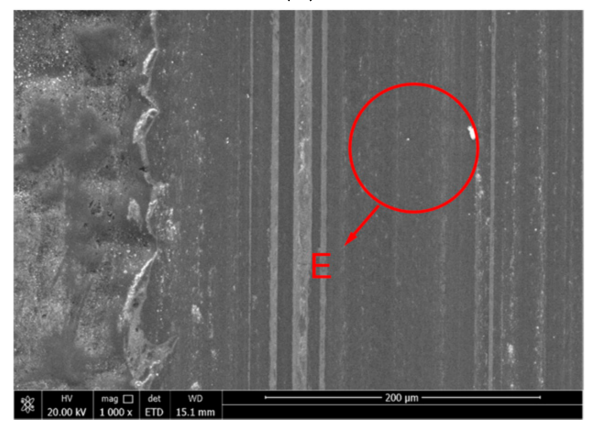

(e)

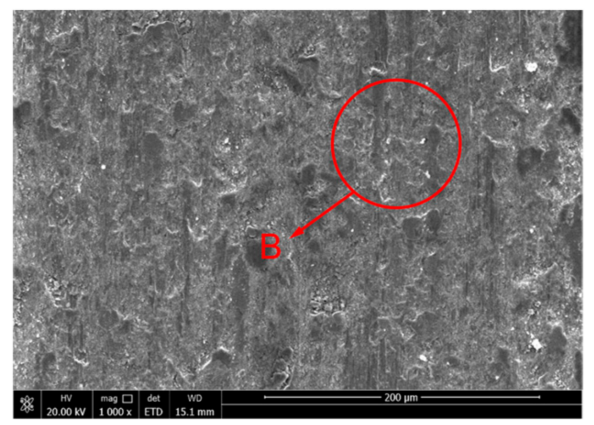

(b)

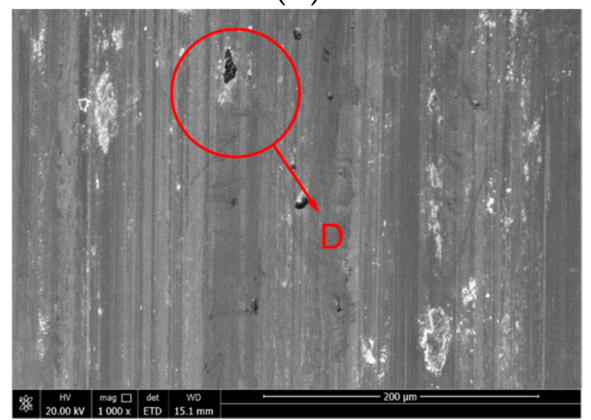

(d)

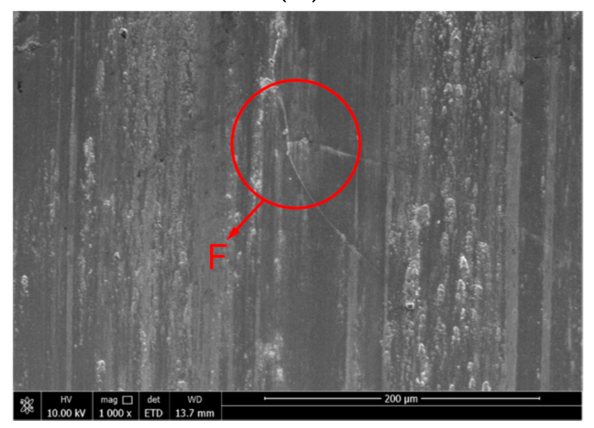

(f)

Figure 9. Surface morphology of wear marks. (a) $30 \mathrm{~A} \cdot \mathrm{dm}^{-2}(\mathrm{~J})$ (b) $20 \mathrm{~A} \cdot \mathrm{dm}^{-2}$ (c) $30 \mathrm{~A} \cdot \mathrm{dm}^{-2}$ (d) $40 \mathrm{~A} \cdot \mathrm{dm}^{-2}$ (e) $50 \mathrm{~A} \cdot \mathrm{dm}^{-2}$ (f) $60 \mathrm{~A} \cdot \mathrm{dm}^{-2}$.

\section{Conclusions}

1. In immersion-assisted jet-electrodepos-ition, the workpiece is in a stable plating bath environment, the temperature is stable, and the cathode can be effectively replenished. Moreover, the limiting current density is improved, and thus the $\mathrm{Ni}-\mathrm{P}$ alloy coating prepared through this process is better than that prepared through jet-electrodeposition. The surface of the coating is smoother, defects such as pits and protrusions are reduced, and hardness and wear resistance are improved; 
2. The surface of the $\mathrm{Ni}-\mathrm{P}$ alloy coating prepared by immersion-assisted jet-electrodeposition exhibits a typical cell structure. With increasing current density, the overpotential of cathode increases and the nucleation rate of surface cells of the subsequently increases. In addition, the surface quality and thickness of the $\mathrm{Ni}-\mathrm{P}$ alloy coating increases first and then decreases. When the current density is $50 \mathrm{~A} \cdot \mathrm{dm}^{-2}$, the cell structure of the coating is uniform, the thickness of the $\mathrm{Ni}-\mathrm{P}$ coating reaches the maximum, which is $21.42 \mu \mathrm{m}$, the boundary is blurred, and the smallest grain size is observed, i.e., the surface quality is the best;

3. The grain size of the Ni-P alloy coating prepared through immersion-assisted jetelectrodeposition decreases first and then increases as current density increases. The reason is that the nucleation rate increases with current density, and this increase contributes to grain refinement. When the current density is $50 \mathrm{~A} \cdot \mathrm{dm}^{-2}$, the grain size reaches a minimum value of $6.6 \mathrm{~nm}$, and the Ni element content reaches a maximum of $98.25 \%$. When the current density continues to increase to $60 \mathrm{~A} \cdot \mathrm{dm}^{-2}$, the P content reaches a maximum of $3.45 \%$;

4. The microhardness of $\mathrm{Ni}-\mathrm{P}$ alloy coatings prepared through immersion-assisted jet-electrodeposition presents a trend of increasing first and then decreasing as current density increases. The reasons are the increase in deposition rate and a dense coating surface without defects after the increase in current density. When the current density reaches the highest average microhardness $\left(725.58 \mathrm{HV}_{0.1}\right)$, it is approximately $46.5 \%$ higher than that when the current density is $20 \mathrm{~A} \cdot \mathrm{dm}^{-2}$, and the effect is remarkable. The increase in hardness is beneficial to the improvement of wear resistance;

5. With increasing current density, the improvement of microhardness of the coating can significantly improves the wear resistance of the coating, and the two are directly proportional. The Ni-P alloy coating prepared by immersion-assisted jetelectrodeposition has the best wear resistance when the current density is $50 \mathrm{~A} \cdot \mathrm{dm}^{-2}$, and the width, depth, and cross-sectional area of the wear scar of the coating are the smallest, which are $425.494 \mu \mathrm{m}, 7.782 \mu \mathrm{m}$ and $2266.533 \mu \mathrm{m}^{2}$, respectively. No obvious furrow and shedding phenomenon or cracks are observed on the surface of the coating wear scar. The friction mechanism is mainly based on abrasive wear.

Author Contributions: Conceptualization, Z.S. and J.X.; methodology, J.X., Z.Z., and Z.S.; software, Z.S. and M.J. (Minjie Jiang); validation, Z.Z. and M.J. (Minjie Jiang); formal analysis, J.X. and Z.S.; investigation, H.W. and M.J. (Meifu Jin); resources, J.X.; data curation, Z.S. and H.W.; writingoriginal draft preparation, J.X. and Z.S.; writing-review and editing, M.J. (Meifu Jin) and H.W.; visualization, Z.S. and Z.Z.; supervision, J.X., M.J. (Minjie Jiang), and Z.Z.; project administration, H.W. and J.X.; funding acquisition, J.X. and M.J. (Meifu Jin). All authors have read and agreed to the published version of the manuscript.

Funding: Financial support for this work was provided by Jiangsu Agricultural Science and Technology Innovation Fund (Grant number CX (20) 3085); Fundamental Research Funds for the Central Universities (Grant number KYXJ202002).

Institutional Review Board Statement: Not applicable.

Informed Consent Statement: Not applicable.

Data Availability Statement: Not applicable.

Conflicts of Interest: The authors declare no conflict of interest.

\section{References}

1. Li, W.S.; Cui, S.; He, L.; Li, Q.K. Electrochemically deposited Ni-based $\mathrm{MoS}_{2}$ composite coating and its wide temperature range friction properties. China Surf. Eng. 2017, 30, 97-103.

2. Ahmadkhaniha, D.; Zanella, C. The Effects of Additives, Particles Load and Current Density on Codeposition of SiC Particles in NiP Nanocomposite Coatings. Coatings 2019, 9, 554. [CrossRef]

3. Benea, L.; Celis, J.P. Effect of Nano-TiC Dispersed Particles and Electro-Codeposition Parameters on Morphology and Structure of Hybrid Ni/TiC Nanocomposite Layers. Materials 2016, 9, 269. [CrossRef] [PubMed] 
4. Rosolymou, E.; Spanou, S.; Zanella, C.; Tsoukleris, D.S.; Köhler, S.; Leisner, P.; Pavlatou, E.A. Electrodeposition of Photocatalytic Sn-Ni Matrix Composite Coatings Embedded with Doped TiO2 Particles. Coatings 2020, 10, 775. [CrossRef]

5. Jiang, W.; Shen, L.; Qiu, M.; Wang, X.; Fan, M.; Tian, Z. Preparation of Ni-SiC composite coatings by magnetic field-enhanced jet electrodeposition. J. Alloys Compd. 2018, 762, 115-124. [CrossRef]

6. Xue, Y.J.; Si, D.H.; Liu, H.B. The influence of electrodeposition methods on the friction and wear properties of $\mathrm{Ni}^{-\mathrm{CeO}} \mathrm{C}_{2}$ nanocomposite coatings. Chin. J. Nonferrous Met. 2011, 21, 2157-2162.

7. Hessam, R.; Najafisayar, P. The effects of applied current density and bath concentration on the morphology, crystal structure and optical properties of electrodeposited hematite thin films. Thin Solid Films 2019, 692, 137633. [CrossRef]

8. Shourije, S.J.; Bahrololoom, M.E. Effect of current density, $\mathrm{MoS}_{2}$ content and bath agitation on tribological properties of electrodeposited nanostructured Ni-MoS 2 composite coatings. Tribol. Mater. Surf. Interfaces 2019, 13, 76-87. [CrossRef]

9. Fan, H.; Zhao, Y.P.; Jiang, J.; Wang, S.; Shan, W.; Ma, R. Pulse jet electrodeposition of nanocrystal line copper and its application as an electrical discharge machining electrode. Int. J. Electrochem. Sci. 2020, 15, 2648-2658. [CrossRef]

10. Song, Z.Y.; Zhang, H.W.; Fu, X.Q. Effect of Current Density on the Performance of Ni-P-ZrO $\mathrm{Z}_{2}-\mathrm{CeO}_{2}$ Composite Coatings Prepared by Jet-Electrodeposition. Coatings 2020, 10, 616. [CrossRef]

11. Qiao, G.Y.; Jing, T.F.; Wang, N.; Gao, Y.; Zhao, X.; Zhou, J.; Wang, W. High-speed jet electrodeposition and microstructure of nanocrystalline Ni-Co alloys. Electrochim. Acta 2005, 51, 85-92. [CrossRef]

12. Rajput, M.S.; Pandey, P.M.; Jha, S. Modelling of high speed selective jet electrodeposition process. J. Manuf. Process. 2015, 17, 98-107. [CrossRef]

13. Tian, J.; Song, H.; Zheng, X.H.; Zhang, Q.; Wang, M. High performance $\mathrm{Co}-\mathrm{Cr}_{3} \mathrm{C}_{2}$ composite coating by jet electrodeposition. Surf. Eng. 2017, 34, 861-869.

14. Ning, D.D.; Zhang, A. Enhanced Wear Performance of Cu-Carbon Nanotubes Composite Coatings Prepared by Jet Electrodeposition. Materials 2019, 12, 392. [CrossRef]

15. Fu, X.Q.; Shen, Z.Y.; Chen, X.X. Influence of Element Penetration Region on Adhesion and Corrosion Performance of Ni-Base Coatings. Coatings 2020, 10, 895. [CrossRef]

16. Singh, C.; Tiwari, S.K.; Singh, R. Exploring environment friendly nickel electrodeposition on AZ91 magnesium alloy: Effect of prior surface treatments and temperature of the bath on corrosion behaviour. Corros. Sci. 2019, 151, 1-19. [CrossRef]

17. Li, T.T.; Ling, L.; Lin, M.C.; Jiang, Q.; Lin, Q.; Lou, C.W.; Lin, J.H. Effects of ultrasonic treatment and current density on the properties of hydroxyapatite coating via electrodeposition and its in vitro biomineralization behavior. Mater. Sci. Eng. C Mater. Biol. Appl. 2019, 105, 110062. [CrossRef]

18. Li, N.B.; Xu, W.H.; Zhao, J.H.; Xiao, G.Y.; Lu, Y.P. The significant influence of ionic concentrations and immersion temperatures on deposition behaviors of hydroxyapatite on alkali- and heat-treated titanium in simulated body fluid. Thin Solid Films 2018, 646, 163-172. [CrossRef]

19. Li, Y.D.; Jiang, H.; Huang, W.H.; Tian, H. Effects of peak current density on the mechanical properties of nanocrystalline Ni-Co alloys produced by pulse electrodeposition. Appl. Surf. Sci. 2008, 254, 6865-6869. [CrossRef]

20. Lelevic, A.; Walsh, F.C. Electrodeposition of Ni P composite coatings: A review. Surf. Coat. 2019, 378, 124803. [CrossRef]

21. He, Y.; Wang, S.C.; Walsh, F.C.; Chiu, Y.L.; Reed, P.A.S. Self-lubricating Ni-P-MoS 2 composite coatings. Surf. Coat. Technol. 2016, 307, 926-934. [CrossRef]

22. Shui, Y. The research status and development trend of Ni-P coating. Surf. Technol. 2002, 1, 1-4.

23. Li, L.; Lu, Z.X.; Pu, J.B.; Wang, H.; Li, Q.; Chen, S.; Zhang, Z.; Wang, L. The superlattice structure and self-adaptive performance of $\mathrm{C}-\mathrm{Ti} / \mathrm{MoS}_{2}$ composite coatings. Ceram. Int. 2020, 46, 5733-5744. [CrossRef]

24. Anas, N.S.; Krishna, L.R.; Dash, R.K.; Vijay, R. Tribological Performance of Al Alloys Dispersed with Carbon Nanotubes or Ni-Coated Carbon Nanotubes Produced by Mechanical Milling and Extrusion. J. Mater. Eng. Perform. 2020, 29, 1630-1639. [CrossRef] 